\title{
The Internationalization Behavior of SMEs from a Purchase Perspective
}

\author{
David Iubel de Oliveira Pereira ${ }^{1}$, Marcelo Gechele Cleto ${ }^{1}$ \\ ${ }^{1}$ Federal University of Paraná, Paraná State, Curitiba, Brazil \\ Correspondence: David Iubel de Oliveira Pereira, Departament of Production Engineering, Federal University of \\ Paraná, Paraná State, Curitiba, Brazil.
}

Received: March 22, 2018

Accepted: April 25, $2018 \quad$ Online Published: May 9, 2018

doi:10.5539/ibr.v11n6p50

URL: https://doi.org/10.5539/ibr.v11n6p50

\begin{abstract}
The aim of present study was to analyze the internationalization behavior of Small and Medium Enterprises (SMEs) regarding purchases using four questions: why, what, when and where. Structured interviews were conducted at SMEs located in the city of Curitiba and Metropolitan Region, Brazil, which dealt with the machinery and equipment sector. Regarding the reasons for internationalization (why), the main results showed agreement with motivators associated with cheaper products, advanced technology, higher quality and exclusivity, as well as an expectation of increasing organizational competitiveness. Internationalization items (what) sought out by SMEs were mostly items considered strategic. Regarding internationalization period (when), younger companies tended to start their internationalization process earlier. However, both the age of the company and the year of international entry did not directly explain or influence international expansion. Finally, place of internationalization (where) showed that a variety of countries have been involved with SMEs since their creation. However, the age of the company and the age of international entry could not directly explain or influence international geographic speed (entry into new countries).
\end{abstract}

Keywords: internationalization behavior, international purchasing, small and medium enterprises

\section{Introduction and Brief Literature Review}

\subsection{Introduce the Problem}

World markets have become more integrated, technology has advanced, and tariff and non-tariff barriers have been brought down (Ståhl, 2000). These factors have gradually lowered the life cycle of products (Kotabe and Murray, 2004). Thus, the dynamics of international trade have undergone changes with the growing search of supplies in the international sphere - regardless of location, segment and size - which generates high local and international competition (Nunes, 2016).

This situation has put pressure on the operating modes of various enterprises. Thus, their actions and investments tend to be more oriented towards international markets, through involvement at different levels with the external market (Quintens et al., 2006a, 2006b; Trent and Monzcka, 2003).

This phenomenon is known as purchase internationalization, or inward internationalization. However, limited attention is still given to internationalization practices from this perspective (Aykol et al., 2013). In fact, most scientific studies focus on the internationalization of sales activities and direct investments abroad, which are also known as outward internationalization (Karlsen et al., 2003; Ligabo Junior, 2015).

Moreover, considering the context of purchase internationalization, there are still few studies that regard imports from Small and Medium Enterprises (SMEs). Unlike large multinational companies that have been more often the focus of academic studies, SMEs present specific characteristics when seeking international supply, such as lower resources to reach a more advanced internationalization stage, or higher sensitivity to external challenges (technology, policy, exchange, institutional environments of international markets, and market changes), which contribute towards greater unpredictability, making it difficult for SMEs to deal with internationalization risks (Ellegaard, 2006; Holmlund et al., 2007; Knudsen and Servais, 2007; Laufs and Schwens, 2014; Laurin and St-Pierre, 2011; Pangarkar, 2008; Quayle, 2002).

Thus, the aim of the present study was to analyze the behavior of purchase internationalization in the context of smaller companies, summarizing the process in four basic questions: why (motives), what (type of items), when 
(period) and where (place), following the recommendations of Carneiro and Dib (2008) and (Dib et al., 2010). The study focused on Brazilian SMEs from the machinery and equipment sector located in the city of Curitiba and Metropolitan Region.

\subsection{Literature Review}

\subsubsection{Internationalization Motives (Why?)}

A systematic literature review was performed to assess which are the main motivations for SMEs to internationalize their purchases. The database and keywords used were based on studies by Quintens et al. (2006a) and Tressin and Richter (2014), who provided reviews of scientific publications regarding international purchases between 1990 and 2005 and between 2006 and 2012, respectively.

Regarding keywords, the aforementioned authors considered the expression "motives" as the element that accelerated the decision for enterprises to embrace international purchases. Moreover, these authors searched for studies on the theme using the terms "international purchasing", "international procurement", "international sourcing", "global purchasing", "global procurement" and "global sourcing" (Quintens et al., 2006b; Tressin and Richter, 2014). Since the present study regarded SMEs, the keyword "Small and Medium Enterprise (SMEs)" was also added to the search.

The databases consulted were composed of 14 journals: The Journal of Supply Chain Management (JSCM); Journal of Purchasing and Supply Management (JPSM); Supply Chain Management: an International Journal (SCM); International Journal of Physical Distribution and Logistics Management (IJPDM); International Journal of Operations and Production Management (IJOPM); Industrial Marketing Management (IMN); European Journal of Marketing (EJM); International Marketing Review (IMR); Journal of International Marketing (JIM); Journal of Business and Industrial Marketing (JBIM); International Business Review (IBR); Management International Review (MIR); Journal of Business Research (JBR); Journal of International Business Studies (JIBS). All journals were considered of great relevance to the topic of international purchases, as reported by Quintens et al. (2006a) and Tressin and Richter (2014).

The main international purchase motivators were defined after including the keywords in the databases and excluding duplicate articles and articles that were not aligned with the research theme, based on a reading of their titles, abstracts and the complete text. Possible related articles were also analyzed. Purchase motivators were classified based on impact and ordered chronologically from oldest publication to most recent one (Table $1)$. 
Table 1. Purchase motivators of companies based on literature review

\begin{tabular}{|c|c|c|c|c|c|c|c|c|}
\hline Author & $\begin{array}{l}\text { Lower } \\
\text { price }\end{array}$ & $\begin{array}{l}\text { Higher } \\
\text { quality }\end{array}$ & $\begin{array}{l}\text { Trust in } \\
\text { delivery }\end{array}$ & $\begin{array}{l}\text { Advanced } \\
\text { technology }\end{array}$ & $\begin{array}{c}\text { Exclusive } \\
\text { product }\end{array}$ & $\begin{array}{l}\text { Increase in } \\
\text { competition }\end{array}$ & $\begin{array}{c}\text { New } \\
\text { market }\end{array}$ & $\begin{array}{c}\text { Supplier } \\
\text { diversification }\end{array}$ \\
\hline $\begin{array}{l}\text { Carter and } \\
\text { Narasimhan, } \\
1990)\end{array}$ & 1 st & 2nd & & $3 \mathrm{rd}$ & 4th & 5 th & & \\
\hline $\begin{array}{l}\text { (Birou and } \\
\text { Fawcett, } \\
1993 \text { ) }\end{array}$ & $1 \mathrm{st}$ & $3 r d$ & & 4th & & 2nd & & 5 th \\
\hline $\begin{array}{l}\text { (Ghymn and } \\
\text { Jacobs, 1993) }\end{array}$ & $3 r d$ & $1 \mathrm{st}$ & 2nd & & & & & 4th \\
\hline $\begin{array}{l}\text { (Rajagopal } \\
\text { and Bernard, } \\
1994)\end{array}$ & 1 st & $3 \mathrm{rd}$ & 4th & & & 2nd & & 5th \\
\hline $\begin{array}{l}\text { (Scully and } \\
\text { Fawcett, } \\
\text { 1994) }\end{array}$ & 1 st & 2nd & & $3 r d$ & 5th & 4th & & \\
\hline $\begin{array}{l}\text { (Rexha and } \\
\text { Miyamoto, } \\
\text { 2000) }\end{array}$ & $2 \mathrm{nd}$ & 4th & & $3 r d$ & $1 \mathrm{st}$ & & & \\
\hline $\begin{array}{l}\text { (Lye and } \\
\text { Hamilton, } \\
\text { 2001) }\end{array}$ & 4th & $1 \mathrm{st}$ & $3 r d$ & & & & 2nd & 5th \\
\hline $\begin{array}{l}\text { (Overby and } \\
\text { Servais, } \\
\text { 2005) }\end{array}$ & $1 \mathrm{st}$ & 2nd & $3 \mathrm{rd}$ & & & & 4th & \\
\hline $\begin{array}{l}\text { (Quintens et } \\
\text { al., 2005) }\end{array}$ & 1 st & 2nd & & & $3 \mathrm{rd}$ & & & \\
\hline $\begin{array}{l}\text { (Agndal, } \\
2006 \text { ) }\end{array}$ & 1 st & 2nd & & & 3rd & & & \\
\hline $\begin{array}{l}\text { (Nassimbeni, } \\
\text { 2006) }\end{array}$ & 1 st & 4th & & $3 \mathrm{rd}$ & 2nd & 5th & & \\
\hline $\begin{array}{l}\text { (Knudsen and } \\
\text { Servais, } \\
\text { 2007) }\end{array}$ & $3 \mathrm{rd}$ & 1 st & & 2nd & 5 th & 4th & & \\
\hline (Lupu, 2008) & 1 st & $3 \mathrm{rd}$ & & 5th & 2nd & 4th & & \\
\hline $\begin{array}{l}\text { (Wang et al., } \\
\text { 2011) }\end{array}$ & 1 st & & $3 \mathrm{rd}$ & & & & 2nd & \\
\hline $\begin{array}{l}\text { (Dantas et al., } \\
\text { 2012) }\end{array}$ & 2 nd & & & $3 \mathrm{rd}$ & $1 \mathrm{st}$ & 4th & 5 th & \\
\hline (Nunes, 2016) & & & 2nd & $1 \mathrm{st}$ & & 4th & 5th & $3 \mathrm{rd}$ \\
\hline
\end{tabular}

One of the most cited motivators for internationalization from a purchase perspective was lower prices overseas (e.g. Overby and Servais, 2005; Quintens et al., 2005; Wang et al., 2011).

Other relevant motivators regarded items that are either unavailable in domestic markets (e.g. Agndal, 2006) or are found with higher levels of quality and technology overseas (e.g. Knudsen and Servais, 2007; Nunes, 2016). This type of situation can generate a competitive differential for enterprises by supplying a strategic item that is scarce in their domestic market. In addition, operating internationally allows access to new markets, possibly guaranteeing a position in future potential markets and bringing a better competitiveness position to the enterprise (e.g. Dantas et al., 2012; Nassimbeni, 2006).

Supply base was also indicated as a motivator. An increase in the number of suppliers may allow a company to obtain greater variety, increase competition among domestic suppliers and not become dependent on a single supplier. An international supplier also allows reduction of delivery time. This can improve performance and promote greater reliability of delivery, which consequently leads to greater customer satisfaction and loyalty (Lye and Hamilton, 2001; Nunes, 2016; Rajagopal and Bernard, 1994).

A Proposition 1 was developed based on the motivators raised: "(1) Lower prices overseas and items with (2) more advanced technology, (3) higher quality and (4) that are not found in the domestic market can (5) increase the company's competitiveness, while an (6) increase in the supply base allows the (7) possibility of obtaining greater delivery reliability, (8) non-dependence, (9) increased competition from domestic suppliers, and the (10) possibility of access and contact with potential new markets abroad, which are all motivators that lead SMEs to internationalize their purchases." 


\subsubsection{Internationalization Items (What?)}

A purchasing portfolio model was used as an analysis tool for the items sought overseas. Items were classified to understand their strategic importance and to analyze different supply base relationships (Ateş et al., 2015; Caniëls and Gelderman, 2005; Kraljic, 1983).

The model proposed by Kraljic (1983) was the main reference consulted. As stated by Caniëls and Gelderman (2005) and Ateş et al. (2015), this model was the first to apply a purchasing portfolio approach and is one of the most relevant studies on this subject in the literature. Items acquired by a company are classified in four categories based on two factors in this model proposed by Kraljic (1983): supply risk and purchase impact. Based on these two dimensions, the author defined four types of purchases: non-critical (low risk, low impact), bottleneck (high risk, low impact), leverage (low risk, high impact) and strategic (high risk, high impact) (Moreira, 2013; Ateş et al., 2015).

The analyses of the empirical studies by Quayle (2002), Agndal (2006), Ellegaard (2006), Lupu (2008), Pressey et al. (2009) and Moreira (2013), which regarded the relationship between international supply and strategic level of SMEs, concluded that international purchases were considered irrelevant and non-strategic, which lead to a low pursuit for foreign products. This conclusion was based on the following common characteristics that were observed in the companies analyzed: priority towards operational issues; inexistence of multidisciplinary purchasing teams; multitasking outside the scope of the objectives of purchasing functions by employees responsible for purchases; purchasing seen as operational; and companies that did not have a strategy and formalized objectives for purchases, worrying exclusively about the price and deadline of delivery. Therefore, international purchase was shown to be regarded as strictly operational and/or tactical by SMEs, which lead to the formulation of a second research proposition:

\section{Proposition 2: "SMEs tend to search few products that are considered strategic in the international market."}

\subsubsection{Internationalization Period (When?)}

Enterprises have the option to start their international activities either at an early stage of their development or at a later time. Moreover, after beginning overseas operations, enterprises may choose to either increase or reduce their international activities and their speed (Bartlett and Ghoshal, 2000; Oviatt and McDougall, 2005).

Thus, according to the literature, SMEs can be separated into two categories regarding the period and speed of international expansion throughout their development: Traditional SMEs and Born Global SMEs (Bell et al., 2003; Carvalho, 2009; Cavusgil and Knight, 2015; Kalinic and Forza, 2012; Knight and Liesch, 2015; Ruzzier et al., 2006). As observed by (Quintens et al., 2005), Agndal (2006), and Knudsen and Servais (2007), although these concepts originally explained outward internationalization (sales perspective), they are completely analogous and applicable to the purchase perspective of inward internationalization.

SMEs categorized as Traditional have conservative characteristics. They focus mainly on the domestic market when beginning their international activity, but usually after the decision to expand internationally they adopt an incremental pattern of internationalization, following the Uppsala Model (Bell et al., 2003; Carvalho, 2009; Cavusgil and Knight, 2015; Kalinic and Forza, 2012; Knight and Liesch, 2015; Ruzzier et al., 2006). This internationalization model proposes that international expansion can be described as a series of increments of international commitment, which means that as a firm gains experience, it becomes more willing to commit resources to international activities, which in turn generates more experiences, and so on (Johanson and Vahlne, 2009, 2003, 1990, 1977).

On the other hand, the Born Global SMEs represent companies that were established after 1990 and which tend to start international activities within the first five years of existence (Carvalho, 2009; Cortezia and de Souza, 2011; Dib et al., 2010; Ribeiro et al., 2012). Their main characteristic is precisely establishing international activities few years after their foundation, with fast expansion in international operations.

Based on these concepts there seems to be a relationship between the age of the company (date of foundation), the year of international entry, and the international expansion/commitment. Thus, the following research propositions were established:

Proposition 3: "For SMEs, the year of international entry is positively related to the age of the enterprise, or in other words, the younger an SME, the earlier the internationalization process begins."

Proposition 4: "For SMEs, the year of international entry is negatively related to the following international growth, or in the other words, the earlier an SME starts to internationalize, the higher its international growth rate will be at a later period." 
Proposition 5: "For SMEs, the age of the enterprise is a moderating force that is negatively related to international growth, or in the other words, the younger an SME, the higher its international growth rate will be at a later period."

\subsubsection{Internationalization Local (Where?)}

The analysis of potential markets overseas was also based on the concepts of Traditional SMEs and Born Global SMEs.

Traditional SMEs, as already noted, have an incremental internationalization pattern. This behavior is also correlated to where they expand internationally. Thus, relationships are usually established first between markets that present geographic, cultural and economic proximity, and as internationalization activities mature, the company tends to expand into new markets, which are close to those already conquered, and so on until reaching international markets (Johanson and Vahlne, 2009, 2003, 1990, 1977).

In turn, geographic distances are less relevant to Born Global SMEs. When these enterprises decide to operate internationally, there is no initial limitation regarding nearer markets, and they present faster reach and expansion in the global market (Bell et al., 2003; Carvalho, 2009; Cavusgil and Knight, 2015; Kalinic and Forza, 2012; Knight and Liesch, 2015; Ruzzier et al., 2006).

Based on these concepts there seems to be a relationship between the age of the company (date of foundation), the year of international entry, and international geographic expansion (number of countries). Thus, the following research propositions were established:

Proposition 6: "For SMEs, the age of the enterprise is negatively related to the initial geographic distance, or in the other words, the younger an enterprise, the more distant is the initial international market."

Proposition 7: "For SMEs, the year of international entry is negatively related to the speed of geographic internationalization, or in the other words, the sooner an SME begins to internationalize, the greater is the pace of geographic expansion abroad (entry into new countries)."

Proposition 8: "For SMEs, the age of the enterprise is negatively related to the following international growth, or in the other words, the younger an enterprise, the greater the pace of geographic expansion abroad (entry into new countries)."

\section{Method}

A structured questionnaire was used to collect data. For the first proposition, the respondents scored each motivator surveyed from the literature using a five-level Likert scale. A score equal to five represented a positive and totally true opinion, while a score equal to one meant a negative and totally false situation. The intermediate situations were scores equal to four (true), three (neither true nor false), and two (false). For the second proposition, the respondents indicated among 4 possible alternatives the one that best described the type of items that are bought abroad in order of quantity, following a scale of four (highest quantity purchased) to one (lowest quantity purchased), according to Kraljic's matrix. For the third, fourth and fifth propositions, the respondents described the year of the enterprises' foundation, the year of the first international purchasing activity, and the percentage of international purchases in relation to total purchases over the first year of international activity and specifically in 2015. Finally, with regard to the sixth, seventh and eighth propositions, the respondents described the countries of their foreign suppliers in the first year of international purchasing activity and also in 2015.

The database selected to search the companies was the Industries Register of Paraná (2016 edition) elaborated by the Federation of Industries of the State of Paraná (FIEP, 2016). In total, 986 companies performed international purchasing activities. Of these 986 companies, 686 companies were SMEs. From this total of 686 SMEs, 111 companies belonged to the machinery and equipment sector, of which 70 were located in the city of Curitiba and Metropolitan Region. Thus, these 70 companies corresponded to the population for analysis.

Over the period of August to November 2016, all 70 companies were contacted by telephone and informed about the research. As a result, 17 questionnaires were answered completely ( 9 answered by the respondent when visited by a researcher at the company, 3 answered by telephone and 5 answered by e-mail). This total corresponded to a return rate of $24.28 \%$, a number slightly higher than previous studies that dealt with international purchases, such as Birou and Fawcett (1993) with 14.9\%, Trent and Monczka (2003) with 9\%, Nassimbeni (2006) with 7.9\%, and Quintens et al. (2005) with $17.8 \%$. 


\section{Results}

\subsection{Internationalization Motives (Why?)}

The respondents scored the motivators surveyed from the literature through a five-level Likert scale. Sample mean and standard deviation were calculated using the values attributed to each motivator and placed in descending order in relation to the mean (Table 2). Thus, (1) lower price, (2) access to materials with advanced technology, (3) superior quality, (4) items that do not exist in the domestic market, and (5) desire to increase competitiveness of the company presented mean value greater than four. On the other hand, (6) increase in the supply base, (7) greater reliability on delivery, (8) non-dependence, (9) increased competition from domestic suppliers, and (10) possibility of gaining access and contact with future new markets presented mean values close to two.

Table 2. Motivators scored by the respondents

\begin{tabular}{lcc}
\hline Motivator (1 less relevant to 5 most relevant) & $\mathrm{x}$ & $\mathrm{s}$ \\
\hline (1) Lower price abroad & 4.412 & 0.87 \\
(2) More advanced technology & 4.353 & 0.70 \\
(3) Higher quality abroad & 4.235 & 0.90 \\
(4) Items that are not found in the domestic market & 4.176 & 0.80 \\
(5) Increase in the company's competitiveness & 4.059 & 1.08 \\
(6) Increase in the supply base & 2.765 & 1.14 \\
(7) Increase in delivery reliability & 2.647 \\
(8) Non-dependence on domestic suppliers & 2.353 & 1.11 \\
(9) Increased competition from domestic suppliers & 2.294 & 1.32 \\
(10) The possibility of access and contact with possible new markets abroad & 2.118 & 1.31 \\
\hline
\end{tabular}

For the next step, the motivators were separated into two groups: first, those with mean value above 4 (motivators 1, 2, 3, 4 and 5), and the second of those with mean value below 3 (motivators 6, 7, 8, 9 and 10). Population mean was then assessed through null and alternative hypotheses testing.

For the first group, the null hypothesis was a mean value equal to $4(\mathrm{H} 0: \mu=4)$ against the alternative hypothesis that the mean value would be lower than $4(\mathrm{H} 1: \mu<4)$. For the second group, the null hypothesis was a mean value equal to $3(\mathrm{H} 0: \mu=3)$ against the alternative hypothesis that the mean value would be greater than 3 ( $\mathrm{H} 1$ : $\mu>3$ ). Student's t-test was applied, since population variance was unknown, with a level of significance equal to $5 \%$. The following formula was used to find the value of the calculated $t:$

$$
t_{\text {calculated }}=\frac{\bar{x}-\mu_{0}}{\frac{s}{\sqrt{n}}}
$$

Where:

$\mathrm{x}=$ sample mean;

$\mu 0=$ fixed value used for comparison

$\mathrm{s}=$ sample standard deviation

$\mathrm{n}=$ sample sizer

Student's $t$-Table was used to find the critical $t$, which was then compared to the calculated $t$. With a confidence level of $95 \%$ and 16 degrees of freedom $(n-1)$, critical $t=1.7459$. A left one-tailed curve with critical $t=-1.7459$ was used to check the first null hypothesis $(\mathrm{H} 0: \mu=4)$. In turn, a right one-tailed curve with critical $\mathrm{t}=1.7459$ was used to check the second null hypothesis $(\mathrm{H} 0: \mu=3)$, following the rule:

\section{If $t$ calculated $<-t$ critical we reject the null hypothesis that $\mu=4$ \\ If t calculated $>$ t critical we reject the null hypothesis that $\mu=3$}

No evidence was found to reject the null hypothesis $\mathrm{H} 0: \mu=4$ for the first group of motivators described. This result means that it is unlikely that these motivators will obtain a mean value lower than $4(\mu<4)$. Similarly, no evidence was found to reject the null hypothesis $\mathrm{H} 0: \mu=3$ for the second group of motivators described. Again, this result means that it is unlikely that these motivators will obtain a mean value higher than $3(\mu>3)$ (Table 3$)$. 
Table 3. Hypothesis Test Results

\begin{tabular}{cccc}
\hline & & First Group & \\
\hline Motivator & $\mathrm{t}$ calculated & $\mathrm{t}$ critical $(\alpha=0,95$ one tailed $)$ & Test result $\left(H_{1}: \mu<4\right)$ \\
1 & 1.95 & -1.7459 & Do not reject $\mathrm{HO}: \mu=4$ \\
2 & 2.07 & -1.7459 & Do not reject $\mathrm{HO}: \mu=4$ \\
3 & 1.07 & -1.7459 & Do not reject $\mathrm{HO}: \mu=4$ \\
4 & 0.89 & -1.7459 & Do not reject $\mathrm{HO}: \mu=4$ \\
5 & 0.22 & -1.7459 & Do not reject $\mathrm{H} 0: \mu=4$ \\
\hline & & Second Group & \\
\hline Motivator & $\mathrm{t}$ calculated & $\mathrm{t}$ critical $(\alpha=0,95$ one tailed $)$ & Test result $\left(H_{1}: \mu>3\right)$ \\
6 & -4.43 & 1.7459 & Do not reject $\mathrm{HO}: \mu=3$ \\
7 & -5.01 & 1.7459 & Do not reject $\mathrm{HO}: \mu=3$ \\
8 & -5.14 & 1.7459 & Do not reject $\mathrm{HO}: \mu=3$ \\
9 & -5.36 & 1.7459 & Do not reject $\mathrm{HO}: \mu=3$ \\
10 & -6.65 & 1.7459 & Do not reject $\mathrm{HO}: \mu=3$
\end{tabular}

Finally, the significance of the results found was calculated considering the statistical power of the test. This analysis measures the sensitivity of a statistical test considering the control of a type II error, which allows the identification of differences for a mean value that is considered true (Montgomey, 2012). The power of the statistical test was assessed for two different values of $\mu^{\prime}\left(\mu^{\prime}=3.5 / 3.4\right)$, considering that if the actual value of $\mu$ is in fact either lower than 4 or greater than 3 , but limited to $\mu^{\prime}$, the generated type II error would be acceptable (Table 4).

Table 4. Results of the Assessment of the Power of the Statistical Test

\begin{tabular}{|c|c|c|}
\hline \multicolumn{3}{|l|}{ First Group } \\
\hline Parameter & 3.5 & 3.4 \\
\hline 1 Lower price abroad & $84 \%$ & $92 \%$ \\
\hline 2 More advanced technology & $93 \%$ & $97.5 \%$ \\
\hline 3 Higher quality abroad & $81 \%$ & $90 \%$ \\
\hline 4 Items not found in the domestic market & $87 \%$ & $94 \%$ \\
\hline 5 Increase in the company's competitiveness & $70 \%$ & $81 \%$ \\
\hline \multicolumn{3}{|l|}{ Second Group } \\
\hline Parameter & 3.4 & 3.5 \\
\hline 6 Increase in the supply base & $67 \%$ & $78 \%$ \\
\hline 7 Increase in delivery reliability & $68 \%$ & $79 \%$ \\
\hline 8 Non-dependence on domestic suppliers & $58 \%$ & $69 \%$ \\
\hline 9 Increased competition from domestic suppliers & $58 \%$ & $69 \%$ \\
\hline 10 Possibility of access and contact with potential new markets abroad & $66 \%$ & $76 \%$ \\
\hline
\end{tabular}

Thus, for the first five motivators, with a confidence level of $90 \%$ and considering, for example , a value of $\mu$ '= 3.5 that should be detected, the statistical power of the test was at a mean percentage of $83 \%$ (range of $70 \%$ to 93\%). Changing the value to $\mu^{\prime}=3.4$ resulted in an increase in the power of the statistical test to a mean percentage of $91 \%$ (range of $81 \%$ to $97.5 \%$ ). This demonstrated that if the real mean value was 3.4, the test would perceive the difference and correctly reject $\mathrm{H} 0$ on average for $91 \%$ of cases.

In turn, considering the five last motivators, again with a confidence of $90 \%$ and considering, for example, a value of $\mu^{\prime}=3.4$ that should be detected, the statistical power of the test was at a mean percentage of $63 \%$ (range 
of $58 \%$ to $68 \%$ ). Changing the value to $\mu^{\prime}=3.5$ resulted in an increase in the power of the statistical test to a mean percentage of $73 \%$ (range of $68 \%$ to $79 \%$ ). This demonstrated that if the real mean value was 3.4 , the test would perceive the difference and correctly reject $\mathrm{H} 0$ on average for $73 \%$ of cases.

\subsection{Internationalization Items (What?)}

Respondents indicated among 4 possible alternatives, according to Kraljic's matrix, the alternative that best described the types of items that were bought abroad by their company in order of quantity on a scale of four (highest quantity purchased) to one (lowest quantity purchased). The frequency of each category of items in relation to the quantity acquired was analyzed based on these values (Figure 1)

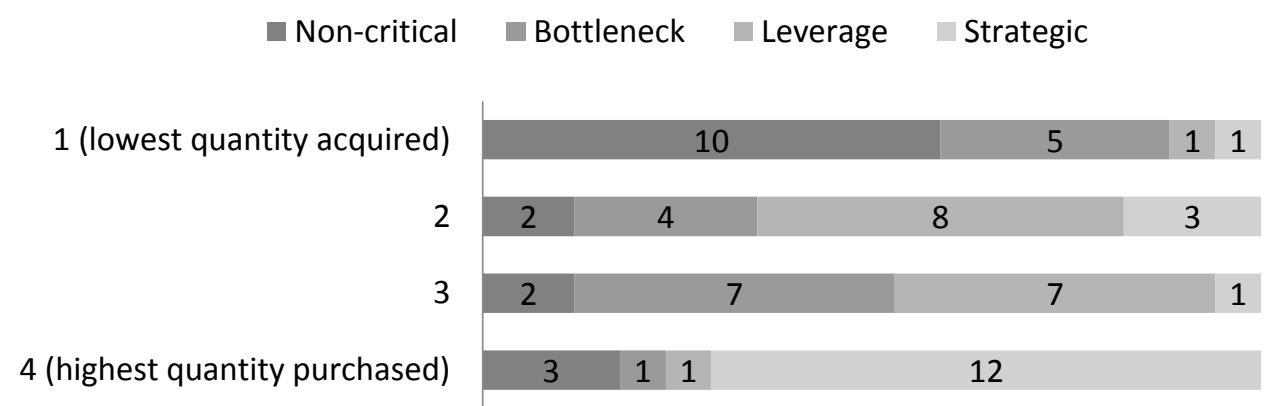

Figure 1. Frequency of items searched abroad by category

The percentage of items considered to have high participation/impact on the profit of the company increased following the quantity of items purchased. Thus, the greater the impact of the item, the greater the quantity purchased. The category of strategic items predominated as the type of item with highest quantity purchased (12 out of 17).

In turn, when assessing the items that are less internationally acquired, products that were considered of lower participation/impact to the profit of the company were less frequent in the categories of higher purchases. A total of 15 low-impact items (10 non-critical and 5 bottlenecks) out of a total of 17 items were observed as having the lowest quantity purchased.

\subsection{Internationalization Period (When?)}

With regard to the internationalization period, the respondents described the year of the company's foundation, the year of first international purchasing activity, and the percentage of international purchases in comparison to total purchases during the first year of international activity and in 2015.

International expansion rate, which translates the speed of internationalization of the enterprise throughout its growth and development trajectory, was calculated in descending order from the most mature enterprise to the youngest. This methodology was adapted from Carvalho (2009) and its results are presented in Table 5:

$$
\% I . E .=\frac{\% \text { international purchases 2015- } \% \text { first international purchases }}{\text { total years of international purchases until } 2015}
$$


Table 5. Description of year of foundation, year of international entry and \% I.E.

\begin{tabular}{cccc}
\hline SME & Foundation year & Years until first international purchase activity & \% International expansion \\
\hline & & Traditional & $3.97 \%$ \\
N & 1973 & 33 & $0.00 \%$ \\
J & 1974 & 11 & $-3.22 \%$ \\
K & 1975 & 14 & $4.34 \%$ \\
L & 1976 & 25 & $0.81 \%$ \\
E & 1980 & 15 & $3.43 \%$ \\
P & 1983 & 7 & $-5.23 \%$ \\
B & 1994 & Born Global & $0.51 \%$ \\
D & 1996 & 5 & $3.09 \%$ \\
F & 1996 & 2 & $1.08 \%$ \\
I & 1996 & 0 & $0.00 \%$ \\
O & 1996 & 4 & $0.83 \%$ \\
G & 1997 & 5 & $0.00 \%$ \\
H & 1999 & 5 & $-7.61 \%$ \\
C & 2003 & 0 & $0.00 \%$ \\
Q & 2004 & 1 & $7.50 \%$ \\
A & 2005 & 0 & $4.72 \%$ \\
M & 2005 & 1 & 1 \\
\hline
\end{tabular}

Pearson's correlation was applied to the data for (1) year of foundation and for (2) years until the first international purchase activity. The results showed strong negative correlation, with a coefficient of determination $r=-0.8746$ (Figure 2). This result demonstrated that the younger the company, the shorter the time period until its first international purchase activity.

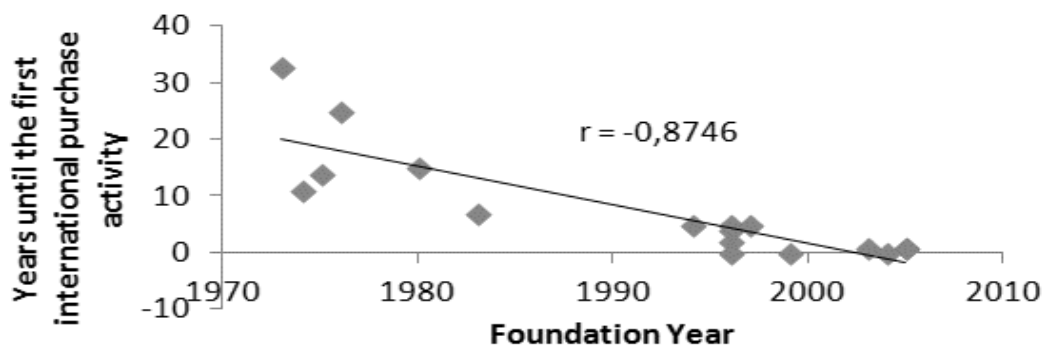

Figure 2. Correlation Graph

A correlation matrix was then created using a 95\% confidence level, and as variables the (1) year of foundation, (2) years until the first international purchase activity and (3) international expansion rate (Table 6).

Table 6. Correlation Matrix

\begin{tabular}{ccc}
\hline & Correlation Matrix & \\
\hline & Year of Foundation & Years until $1^{\text {st }}$ international purchase \\
activity & I.E. \\
Year of foundation & 1 & 1 \\
Years until $1^{\text {st }}$ international purchase & $\mathrm{r}=-0.8746$ & $\mathrm{r}=0.1812$ \\
activity & $\mathrm{p}$ value $=0.00000$ & $\mathrm{p}=$ value 0.4865 \\
\hline I. E. & $\mathrm{r}=-0.0303$ & 1 \\
\hline
\end{tabular}

In relation to the rate of international expansion there was a weak correlation considering all variables (-0.03 with the year of foundation and 0.1812 with the number of years until the company's first international purchase activity). Moreover, $\mathrm{p}$ values were above 0.05 , showing that there was no statistical significance between the variables. This means that it was not statistically possible, considering the sample collected, to form a relationship between international expansion rates and either the year of foundation or the number of years until the first activity of international purchases. 


\subsection{Internationalization Local (Where?)}

Respondents described the countries of their foreign suppliers during the first year of international purchasing activity and in 2015 (Table 7).

Table 7. Description of international suppliers during the 1st year of SMEs and in 2015

\begin{tabular}{ccc}
\hline SME & Place of $1^{\text {st }}$ international purchase activity & 2015 \\
\hline A & China & China \\
B & USA, Germany and Japan & USA, Germany and Japan \\
C & Italy & Italy, Netherlands and Germany \\
D & Germany & Germany \\
E & Germany and China & Germany, China, Switzerland, Taiwan, \\
F & Italy and Germany & Malaysia, South Korea, Sweden and Japan \\
G & USA & Italy, USA, France, Germany, Netherlands and Poland \\
H & USA and China & USA, Italy, Mexico, Sweden, Israel, Germany and China \\
I & Italy & USA and China \\
J & Italy and Germany & Italy, USA, Argentina and China \\
K & Germany & Italy, Germany and China \\
L & Austria & Germany, Italy and USA \\
M & Italy, Poland, USA and Netherlands & Austria, Denmark and Netherlands \\
N & USA, Spain, Italy and China & Italy, Poland, USA, Netherlands and China \\
O & Uruguay, Spain, China and South Korea & USA, Spain, Italy and China \\
P & Italy and USA & Spain, China and South Korea \\
Q & Italy & Italy, USA, China, Japan and Taiwan
\end{tabular}

The rate of international geographic speed was calculated in descending order from the most mature enterprise to the youngest one, as listed in Table 8. This rate corresponded to the international geographic expansion rate of the company over a certain time period after its first international purchase, a methodology adapted from Carvalho (2009):

$$
\% I . G . S=\frac{\begin{array}{c}
\text { the number of different countries in } 2015 \text { in } \\
\text { relation to the first international purchase activity }
\end{array}}{\text { total years of international purchases until } 2015}
$$

\begin{tabular}{|c|c|c|c|}
\hline SME & Foundation Year & Years until the first international purchase activity & $\%$ I.G.S. \\
\hline \multicolumn{4}{|c|}{ Traditional } \\
\hline $\mathrm{N}$ & 1973 & 33 & $0.00 \%$ \\
\hline $\mathrm{J}$ & 1974 & 11 & $3.23 \%$ \\
\hline $\mathrm{K}$ & 1975 & 14 & $7.41 \%$ \\
\hline $\mathrm{L}$ & 1976 & 25 & $13.33 \%$ \\
\hline E & 1980 & 15 & $28.57 \%$ \\
\hline $\mathrm{P}$ & 1983 & 7 & $11.54 \%$ \\
\hline \multicolumn{4}{|c|}{ Born Global } \\
\hline B & 1994 & 5 & $0.00 \%$ \\
\hline $\mathrm{D}$ & 1996 & 2 & $0.00 \%$ \\
\hline $\mathrm{F}$ & 1996 & 0 & $20.00 \%$ \\
\hline I & 1996 & 4 & $18.75 \%$ \\
\hline $\mathrm{O}$ & 1996 & 5 & $0.00 \%$ \\
\hline $\mathrm{G}$ & 1997 & 5 & $42.86 \%$ \\
\hline $\mathrm{H}$ & 1999 & 0 & $0.00 \%$ \\
\hline $\mathrm{C}$ & 2003 & 1 & $16.67 \%$ \\
\hline $\mathrm{Q}$ & 2004 & 0 & $8.33 \%$ \\
\hline A & 2005 & 1 & $0.00 \%$ \\
\hline M & 2005 & 1 & $10.00 \%$ \\
\hline
\end{tabular}

Table 8. Description of year of foundation, year of international entry and \% I.G.S. 
A correlation matrix was then created using a 95\% confidence level, and as variables the (1) year of foundation, (2) years until the first international purchase activity and (3) rate of international geographic speed (Table 9).

Table 9. Correlation Matrix

\begin{tabular}{|c|c|c|c|}
\hline \multicolumn{4}{|c|}{ Correlation Matrix } \\
\hline & Year of foundation & $\begin{array}{c}\text { Years until } 1^{\mathrm{st}} \text { international } \\
\text { purchase activity }\end{array}$ & \% I.G.S. \\
\hline Year of foundation & 1 & & \\
\hline $\begin{array}{c}\text { Years until } 1^{\text {st }} \text { international purchase } \\
\text { activity }\end{array}$ & $\begin{array}{c}\mathrm{r}-0.8746 \\
\mathrm{p} \text { value } 0.00000\end{array}$ & 1 & \\
\hline$\%$ I.G.S. & $\begin{array}{c}\text { r } 0.0294 \\
\text { p value } 0.9109\end{array}$ & $\begin{array}{c}\mathrm{r}-0.0404 \\
\mathrm{p} \text { value } 0.8776\end{array}$ & 1 \\
\hline
\end{tabular}

A weak correlation was observed among all variables in relation to the rate of international geographic speed (0.0294 with the year of foundation and -0.0404 with the number of years until the company's first international purchase activity). Moreover, $\mathrm{p}$ values were above 0.05 , showing that there was no statistical relevance between the variables. This means that it was not statistically possible, considering the sample collected, to form a relationship between rate of international geographic speed and either year of foundation or number of years until the first international purchase activity.

\section{Results Analysis}

Regarding the first research proposition, the results presented demonstrated that five of the ten motivators surveyed from the literature were considered relevant for the search of overseas products for SMEs. In sum, according to Nassimbeni (2006), Knudsen and Servais (2007), and Liviu Lupu (2008), SMEs use the international market mainly to search for lower costs, to address lack of technology and quality, to procure items that are not found in the domestic market, and to meet the expectation of increasing competitiveness. In turn, SMEs denied using the international market to increase their supply base, to obtain greater delivery reliability, to increase competition, to not become dependent on national suppliers, nor mainly to have the possibility of access and contact with potential new markets abroad. This could reveal that the Brazilian market often does not offer products that are advantageous to SMEs, which can be exemplified by the answers of SMEs F and M, for example, which reported facing great difficulty in finding national products with levels of quality, technology and innovation that meet market requirements. Thus, both SMEs considered that it was faster and cheaper to search for products overseas than investing in domestic suppliers.

The results for the international items (what) in the present study diverged in relation to the findings of Quayle (2002), Ellegard (2006), Agnadal (2006), Lupu (2008) and Moreira (2013). SMEs were found to use the international market to search for items that are considered strategic, which led to the rejection of the second research proposition. This finding could be correlated with the previously discussed motivators. SMEs were shown to internationalize their purchases because of the advantages of some products (price, technology, quality, exclusivity), which could consequently increase organizational competitiveness.

Internationalization period (when) was found to be in agreement with the third research proposition, i.e. younger companies tend to start their internationalization process earlier on. This result could indicate that advances in information, communication and transport technologies, allied with reductions in tariff and non-tariff barriers, have resulted in the increasingly common phenomenon of premature internationalization (Ståhl, 2000; Kotabe and Murray, 2004; Nunes, 2016). However, the fourth and fifth propositions could not be neither proven nor rejected, i.e. in principle both the age of the company and the year of international entry did not directly explain nor influence international expansion.

Finally, regarding places chosen for international expansion (where), neighboring markets were not considered attractive for the first international activities, regardless of year of foundation, which rejects the sixth proposition. The seventh and eight propositions could not be neither accepted nor rejected. Thus, the age of the company and the year of international entry could not directly explain or influence the speed of geographic internationalization.

\section{Conclusions}

Significant changes in international trade dynamics (integration of world markets, advances in technology and the breakdown of tariff and non-tariff barriers, as well as the gradually lower life cycle for most products) have led to a growing search for global suppliers, regardless of location, segment and size.

SMEs, with the expectation to increase their organizational competitiveness, have tended to be motivated mainly by the search for products that are considered strategic to operate earlier abroad in several countries that are not 
near to their local markets. However, the age of the enterprise and the year of international entry did not directly explain or influence neither international expansion nor international geographic speed.

These were the main findings of the present study, which had the objective of analyzing the purchase internationalization behavior of small and medium enterprises belonging to the machinery and equipment sector located in the city of Curitiba and Metropolitan Region, Brazil.

The list of companies consulted originated from the register of the industries of the state of Paraná (2016 edition), elaborated by the Federation of Industries of the State of Paraná (FIEP). The sample size was smaller than expected and the return rate of the questionnaires was modest. Thus, results should be seen as what could be extracted from the data collected in view of deadlines and resources available.

Sample size represented a limitation in the present study. Some statistical inferences were not possible to be drawn from the results of this study due to this limitation (i.e. finding a relationship between international expansion rate and geographic internationalization speed with the age of the company and the year of international entry). Thus, a substantially larger sample is suggested.

Another limitation of the present investigation would be the methodological choice adopted to study temporal variables. Ideally, a longitudinal study should be carried out, gathering information from companies in all their activity, not only during the first and last previously determined periods. This, of course, would allow testing the propositions with more statistical rigor.

In addition, the selection of small and medium-sized import companies of the machinery and equipment sector located in the city of Curitiba and Metropolitan Region, state of Paraná, also represented a limitation to the present study. Thus, the results presented herein might not be in agreement with those of companies from other sectors and locations, and of different sizes. Therefore, it would be highly desirable to test the propositions formulated in the present study with samples from other sectors, sizes, states, and regions.

Nevertheless, the present study brings contributions to other investigations seeking to analyze the internationalization behavior of SMEs. Moreover, the authors sincerely desire that this study will stimulate new research that will deepen the findings reported herein.

\section{References}

Agndal, H. (2006). The purchasing market entry process - A study of 10 Swedish industrial small and medium-sized enterprises. Journal of Purchasing and Supply Management, 12(4), 182-196. https://doi.org/10.1016/j.pursup.2006.10.004

Ateş, M. A., Wynstra, F., \& van Raaij, E. M. (2015). An exploratory analysis of the relationship between purchase category strategies and supply base structure. Journal of Purchasing and Supply Management, 21(3), 204-219. https://doi.org/10.1016/j.pursup.2015.04.007

Aykol, B., Palihawadana, D., \& Leonidou, L. C. (2013). Research on the import activities of firms 19602010. Management International Review, 53(2), 215-250. https://doi.org/10.1007/s11575-012-0143-2

Bartlett, C. A., \& Ghoshal, S. (2000). Going Global. Harvard Business Review, 78(2), 132-141.

Bell, J., McNaughton, R., Young, S., \& Crick, D. (2003). Towards an integrative model of small firm internationalisation. Journal of International Entrepreneurship, 1(4), 339-362. https://doi.org/10.1023/A:1025629424041

Birou, L. M., \& Fawcett, S. E. (1993). International purchasing: Benefits, requirements, and challenges. Journal of Supply Chain Management, 29(1), 27-37. https://doi.org/10.1111/j.1745-493X.1993.tb00004.x

Caniels, M. C., \& Gelderman, C. J. (2005). Purchasing strategies in the Kraljic matrix-A power and dependence perspective. Journal of Purchasing and Supply Management, 11(2-3), 141-155. https://doi.org/10.1016/j.pursup.2005.10.004

Carneiro, J. M. T., \& Dib, L. A. (2008). Avaliação comparativa do escopo descritivo e explanatório dos principais modelos de internacionalização de empresas. Internext, 2(1), 1-25.

Carter, J. R., \& Narasimhan, R. (1990). Purchasing in the international marketplace: implications for $\begin{array}{llll}\text { operations. Journal of Supply } & \text { Chain }\end{array}$ https://doi.org/10.1111/j.1745-493X.1990.tb00506.x

Carvalho, S. (2009). Idade de entrada internacional, velocidade de internacionalização e seus efeitos sobre o crescimento no exterior de pequenas e médias empresas (Doctoral dissertation). Retrieved from http://hdl.handle.net/10438/4562 
Cavusgil, S. T., \& Knight, G. (2015). The born global firm: An entrepreneurial and capabilities perspective on early and rapid internationalization. Journal of International Business Studies, 46(1), 3-16. https://doi.org/10.1057/jibs.2014.62

Cortezia, S. L. D., \& de Souza, Y. S. (2011). An analysis of the internationalization of small Brazilian software companies. Brazilian Business Review (English Edition), 8(4). https://doi.org/10.15728/bbr.2011.8.4.2 Dantas, B., Arkader, R., \& Figueiredo, O. (2012). A Comparative Study of Italian and Brazilian International Sourcing Practices. Piccola Impresa/Small Business, (2).

Dib, L. A., Da Rocha, A., \& Da Silva, J. F. (2010). The internationalization process of Brazilian software firms and the born global phenomenon: Examining firm, network, and entrepreneur variables. Journal of International Entrepreneurship, 8(3), 233-253. https://doi.org/10.1007/s10843-010-0044-z

Ellegaard, C. (2006). Small company purchasing: A research agenda. Journal of Purchasing and Supply Management, 12(5), 272-283. https://doi.org/10.1016/j.pursup.2006.08.004

Ghymn, K. I., \& Jacobs, L. W. (1993). Import purchasing decision behaviour: an empirical study of Japanese import managers. International Marketing Review, 10(4). https://doi.org/10.1108/02651339310047556

Holmlund, M., Kock, S., \& Vanyushyn, V. (2007). Small and medium-sized enterprises' internationalization and the influence of importing on exporting. International Small Business Journal,25(5), 459-477. https://doi.org/10.1177/0266242607080655

Johanson, J., \& Vahlne, J. (1977). Process of the the Internationalization Development Firm-a Model of Knowledge Foreign and Increasing Market Commitments. Journal of International Business Studies, 8(1), 23-32. https://doi.org/10.1057/palgrave.jibs.8490676

Johanson, J., \& Vahlne, J. E. (1990). The mechanism of internationalisation. International Marketing Review, 7(4). https://doi.org/10.1108/02651339010137414

Johanson, J., \& Vahlne, J. E. (2003). Business relationship learning and commitment in the internationalization process. Journal of International Entrepreneurship, 1(1), 83-101. https://doi.org/10.1023/A:1023219207042

Johanson, J., \& Vahlne, J. E. (2009). The Uppsala internationalization process model revisited: From liability of foreignness to liability of outsidership. Journal of International Business Studies, 40(9), 1411-1431. https://doi.org/10.1057/jibs.2009.24

Kalinic, I., \& Forza, C. (2012). Rapid internationalization of traditional SMEs: Between gradualist models and born globals. International Business Review, 21(4), 694-707. https://doi.org/10.1016/j.ibusrev.2011.08.002

Karlsen, T., Silseth, P. R., Benito, G. R., \& Welch, L. S. (2003). Knowledge, internationalization of the firm, and inward-outward connections. Industrial Marketing Management, 32(5), 385-396. https://doi.org/10.1016/S0019-8501(03)00012-9

Knight, G. A., \& Liesch, P. W. (2016). Internationalization: From incremental to born global. Journal of World Business, 51(1), 93-102. https://doi.org/10.1016/j.jwb.2015.08.011

Knudsen, M. P., \& Servais, P. (2007). Analyzing internationalization configurations of SME's: The purchaser's perspective. Journal of Purchasing and Supply Management, 13(2), 137-151. https://doi.org/10.1016/j.pursup.2007.06.002

Kotabe, M., \& Murray, J. Y. (2004). Global sourcing strategy and sustainable competitive advantage. Industrial marketing management, 33(1), 7-14. https://doi.org/10.1016/j.indmarman.2003.08.004

Kraljic, P. (1983). Purchasing must become supply management. Harvard business review, 61(5), 109-117.

Laufs, K., \& Schwens, C. (2014). Foreign market entry mode choice of small and medium-sized enterprises: A systematic review and future research agenda. International Business Review, 23(6), 1109-1126. https://doi.org/10.1016/j.ibusrev.2014.03.006

Laurin, F., \& St-Pierre, J. (2011). The internationalisation of SMEs and the relationships between imports and exports. In 2nd International iSME Conference. Retrieved from https://www.researchgate.net/profile/Josee_St-Pierre/publication/265885228_THE_INTERNATIONALISA TION_OF_SMES_AND_THE_RELATIONSHIPS_BETWEEN_IMPORTS_AND_EXPORTS/links/54b3a 5860cf2318f0f9557eb.pdf

Ligabo Júnior, M. (2015). Internacionalização inward: um estudo exploratório no contexto de gestores de recursos. (Master's thesis). Retrieved from http://hdl.handle.net/11224/1339 
Lupu, L. (2008). International Purchasing in Small and Medium-Sized Danish Manufacturing Companies. Univserdidade de Vaasa. (Master's thesis).

Lye, A., \& Hamilton, R. T. (2001). Importer perspectives on international exchange relationships. International Business Review, 10(1), 109-128. https://doi.org/10.1016/S0969-5931(00)00044-5

Moreira, S. M. D. R. (2013). Definição de estratégias para a gestão de compras: estudo de caso (Doctoral dissertation). Retrieved from: http://hdl.handle.net/1822/28522

Nassimbeni, G. (2006). International sourcing: Empirical evidence from a sample of Italian firms. International Journal of Production Economics, 103(2), 694-706. https://doi.org/10.1016/j.ijpe.2006.01.003

Nunes, M. P. (2016). Motivations, risks, barriers, and results associated with the adoption of global sourcing by Brazilian companies: a case-based study. BBR-Brazilian Business Review, 13(2). https://doi.org/10.15728/bbr.2016.13.2.6

Overby, J. W., \& Servais, P. (2005). Small and medium-sized firms' import behavior: The case of Danish industrial purchasers. Industrial Marketing $\quad$ Management, 34(1), 71-83. https://doi.org/10.1016/j.indmarman.2004.08.001

Oviatt, B. M., \& McDougall, P. P. (2005). The internationalization of entrepreneurship. Journal of International Business Studies, 36(1), 2-8. https://doi.org/10.1057/palgrave.jibs.8400119

Pangarkar, N. (2008). Internationalization and performance of small-and medium-sized enterprises. Journal of world business, 43(4), 475-485. https://doi.org/10.1016/j.jwb.2007.11.009

Pressey, A. D., Winklhofer, H. M., \& Tzokas, N. X. (2009). Purchasing practices in small-to medium-sized enterprises: An examination of strategic purchasing adoption, supplier evaluation and supplier capabilities. Journal of purchasing and supply management, 15(4), 214-226. https://doi.org/10.1016/j.pursup.2009.03.006

Quayle, M. (2002). Purchasing in small firms. European Journal of Purchasing \& Supply Management, 8(3), 151-159. https://doi.org/10.1016/S0969-7012(02)00005-9

Quintens, L., Matthyssens, P., \& Faes, W. (2005). Purchasing internationalisation on both sides of the Atlantic. Journal of Purchasing and Supply Management, 11(2-3), 57-71. https://doi.org/10.1016/j.pursup.2005.10.003

Quintens, L., Pauwels, P., \& Matthyssens, P. (2006a). Global purchasing strategy: Conceptualization and measurement. Industrial Marketing Management, 35(7), 881-891. https://doi.org/10.1016/j.indmarman.2006.05.009

Quintens, L., Pauwels, P., \& Matthyssens, P. (2006b). Global purchasing: State of the art and research directions. Journal of purchasing and supply management, 12(4), 170-181. https://doi.org/10.1016/j.pursup.2006.10.006

Rajagopal, S., \& Bernard, K. N. (1994). Global procurement: motivations and strategy. Marketing Intelligence \& Planning, 12(9), 4-17. https://doi.org/10.1108/02634509410069074

Rexha, N., \& Miyamoto, T. (2000). International sourcing: an Australian perspective. Journal of Supply Chain Management, 36(4), 27-34. https://doi.org/10.1111/j.1745-493X.2000.tb00067.x

Ribeiro, F. C. F. (2012). Born Globals brasileiras: estudo da internacionalização de empresas de base tecnológica (Doctoral dissertation, Universidade de São Paulo). 10.11606/T.12.2012.tde-26032012-205850

Ruzzier, M., Hisrich, R. D., \& Antoncic, B. (2006). SME internationalization research: past, present, and future. Journal of small business and enterprise development, 13(4), 476-497. https://doi.org/10.1108/14626000610705705

Scully, J. I., \& Fawcett, S. E. (1994). International procurement strategies: Challenges and opportunities for the small firm. Production and Inventory Management Journal, 35(2), 39. Retrieved from https://search.proquest.com/openview/50eec3b24d2fa945a6a58507cef2735a/1?pq-origsite=gscholar\&cbl=3 6911

Ståhl, B. (2000). Buying abroad: the case of inward internationalisation processes. Företagsekonomiska institutionen. URN urn:nbn:se:uu:diva-2481

Trent, R. J., \& Monczka, R. M. (2003). International purchasing and global sourcing-what are the 
differences? Journal of Supply Chain Management, 39(3), 26-36. https://doi.org/10.1111/j.1745-493X.2003.tb00162.x

Tressin, T., \& Richter, N. F. (2014). Determinants of International Purchasing Success: An Analysis of the Status Quo of Research. Management and Organizational Studies, 1(2), 129. https://doi.org/10.5430/mos.v1n2p129

Wang, J., Singh, P. J., Samson, D., \& Power, D. (2011). Sourcing from China: experiences of Australian firms. Supply Chain Management: An International Journal, 16(6), 419-427. https://doi.org/10.1108/13598541111171138

\section{Copyrights}

Copyright for this article is retained by the author(s), with first publication rights granted to the journal.

This is an open-access article distributed under the terms and conditions of the Creative Commons Attribution license (http://creativecommons.org/licenses/by/4.0/). 